\title{
【特 集：廃棄物の熱処理とエネルギー回収を取り巻く動向について】
}

\section{高効率発電のための廃棄物処理技術の動向}

宇 野晋*

【要 旨】 廃棄物発電については, 全施設平均発電効率は約 $11.9 \%$ と低いものの, 今後 5 年間の竣工予 定施設の平均発電効率は $20 \%$ 以上であり, 確実に高効率化が進んでいる。また, 燒却施設とメタンガ ス化施設のコンバインド施設や 100 200 ton/日の小規模の高効率発電施設の竣工が予定されているな ど, 廃棄物処理を取り巻く状況は着実に変化している。工業会にて関与した 2014 (平成 26) 年度から久 タートしたエネルギー回収型廃棄物処理施設整備マニュアルの内容を一部紹介寸るとともに, さらなる 効率の向上技術として EGR (排ガス再循環) + SNCR (無触媒脱硝) や廃熱ボイラの高温高圧化, 脱硝触 媒の現地再生, 飛灰循環, 膜処理による排水リサイクルシステム等を紹介する。

キーワード: 廃棄物発電, メタンガス化施設, エネルギー回収型, エネルギー供給拠点

\section{1.は じめに}

2012 年 7 月から再生可能エネルギーの固定価格買取 制度（以下, FIT 制度）がスタートした。本制度は既 存施設も対象となったことから, 廃棄物処理施設におい ても多数の施設が電気事業者による新エネルギー等の利 用に関する特別措置法 (RPS 制度) から FIT 制度へ移 行しており,さらなる廃棄物発電の普及ならびに発電効 率の向上が望まれている。

また, 東日本大震災以降, 廃亲物処理施設に対して防 災拠点, エネルギー供給拠点としての役割を担う検討が 各種委員会等で進められており, エネルギーの地産地消 へ向けた取り組みも進行している。

(一社) 日本環境衛生施設工業会（以下, 工業会）では, 2014 年度に環境省からの受託事業として「エネルギー 回収型廃棄物処理施設整備マニュアル ${ }^{1)}$ (以下, マ ニュアル）の作成に携わり，今後の廃棄物発電の目標数 值や新しい効率向上技術等を提案している。

本稿では, マニュアルで議論となった事項を中心に, 高効率発電へ向けた最新動向を報告する。

原稿受付 2015.2.2

*(-补)日本環境衛生施設工業会 技術委員会（侏タクマ） 連絡先：干 103-0012 東京都中央区日本橋堀留町 2-8-4

\section{2. 廃棄物発電の現状}

\section{1 環境省調査データ}

環境省の一般廃棄物処理実態調査結果 平成 24 年度焼 却施設整備状況 ${ }^{2)}$ によると, 焼却施設数は 1,188 施設, 処理能力の合計は 184,117 ton/日であり, 平均焼却能力 は 155 ton/日となる。

2012 (平成 24) 年度に実際に焼却処理された廃棄物量 は 3,399 万 ton/年であるので, 280 日/年で処理したと すると $33,990,000 / 280=121,393$ ton/日となり, 処理能 力 $184,117 \mathrm{ton} /$ 日の拉むね $66 \%$ に相当する。あくまで 机上の計算であるが, この余力の $34 \%$ 相当に相当する 約 62,000 ton/日の処理能力を, 災害廃棄物の処理, ま たは産業廃衰物や未利用バイオマスとの混焼によるさら なる発電量の増加等に有効活用する方策の検討が必要で ある。

図 1 に一般廃棄物処理施設の規模別分布（施設数）を， 図 2 に同 (処理能力) を示す。施設数は, 100 ton/日未 満の施設で 604 施設あり全体の約 50\%を占めるにもか かわらず，ほとんどが発電設備を有していない。一方, 処理能力で整理すると, 100 ton/日以上 200 ton/日未満 の施設規模が一番処理能力が大きく, 全体の約 $22 \%$ に 相当するが, 発電設備を有するのは約 $26 \%$ に留まる。

今後はまずこの規模の発電施設化が望まれているとこ ろである。 


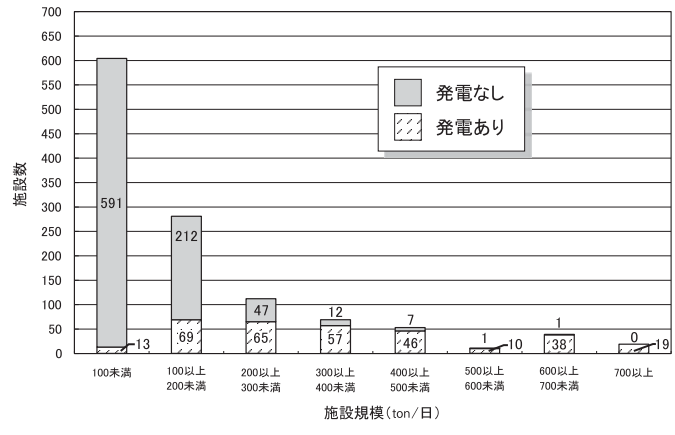

図 1 一般廃棄物処理施設の規模別分布（施設数）

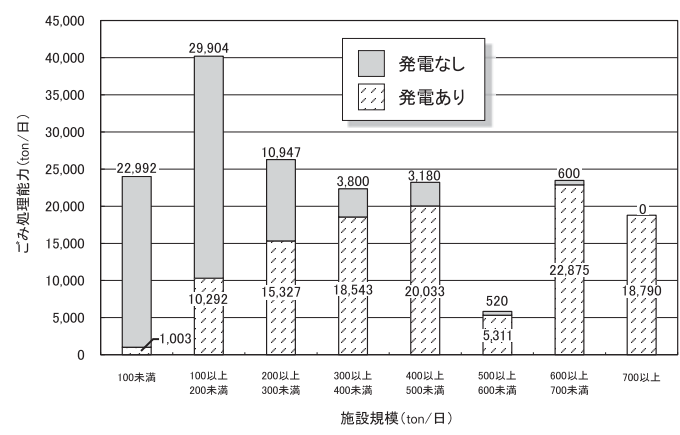

図 2 一般廃棄物処理施設の規模別分布（処理能力）

\section{2 メタンガス化施設の竣工}

一般廃棄物処理施設においてメタン発酵の単独施設は 既に数施設の実績があるが，焼却施設とメタンガス化施 設のコンバインド施設として，

・南但クリーンセンター：

2013 年 5 月竣工, 焼却 43 ton $/$ 日 $\times 1$ 系列,

メタン 36 ton $/$ 日 $\times 1$ 系列

・防府市クリーンセンター：

2014 年 3 月竣工, 焼却 75 ton/日 $\times 2$ 系列,

メタン 25.75 ton/日 $\times 2$ 系列

の 2 施設が相次いで稼働した。

また, 京都市（2019 年 3 月竣工予定, 焼却 $250 \mathrm{ton} /$ 日 $\times 2$ 系列, メタン 30 ton/ 日 $\times 2$ 系 列）が現在建設中である。

南但クリーンセンターについては, 本来単純 焼却施設規模（30 ton/日 $\times 2$ 炉程度）であっ たが, メタン発酵を導入することにより最大 $382 \mathrm{~kW}$ の発電が可能である。施設建設中に FIT 制度が施行されたことから, 竣工後 2 回 線受電に改造している。また, 防府市クリーン センターは, メタン発酵のバイオガスを燒却炉 側の廃熱ボイラの独立過熱器等でコンバイン
ドすることにより，150 ton/日規模で発電効率 23.5\%を 誇っており, 両施設ともに見学者が多数訪れる注目の施 設である。

\section{3 今後 5 年間に竣工する施設の発電効率}

平成 25 年 5 月に閣議決定された廃棄物処理施設整備 計画において, 期間中（2013～2017 (平成 25～29）年度) に整備されるごみ焼却施設の平均発電効率を $21 \%$ とす る重点目標を掲げている。

施設の整備期間が一般的に 3 ～年であることを考慮 すると, この目標期間に整備される施設は既に着工して いるところも多数あることから, 工業会にて状況を調査 した。図 3 に 2013 2017 (平成 25～29) 年度竣工予定施 設の発電効率を, 併せて 2012 (平成 24) 年度竣工施設の 発電効率データを示す。

図からわかるよう全体的に高効率な発電施設の竣工が 予定されており，2013２017 (平成 25～29) 年度竣工予 定施設の平均発電効率（施設規模の加重平均）は $20 \%$ を超える。特に 100～200 ton/日は，発電効率 20\%前後 の施設が 7 施設ほどあり, 小規模ながら $4 \mathrm{MPa}, 400{ }^{\circ} \mathrm{C}$ の蒸気条件による高効率化を実現している。

\section{2014 (平成 26) 年度循環型交付金の検討}

\section{1 エネルギー回収率}

2013 (平成 25) 年度までの高効率ごみ発電施設の交付 メニューは，ユーザーである自治体側からの利用しやす いという点で評判も良く, 近年の廃衰物処理施設の発電 効率の向上に寄与している。

2014 (平成 26) 年度の交付メニューの検討にあたって は, 高効率ごみ発電施設メニューの考え方を踏襲しつつ さらなる未利用エネルギーの有効利用を図るべく, 発電

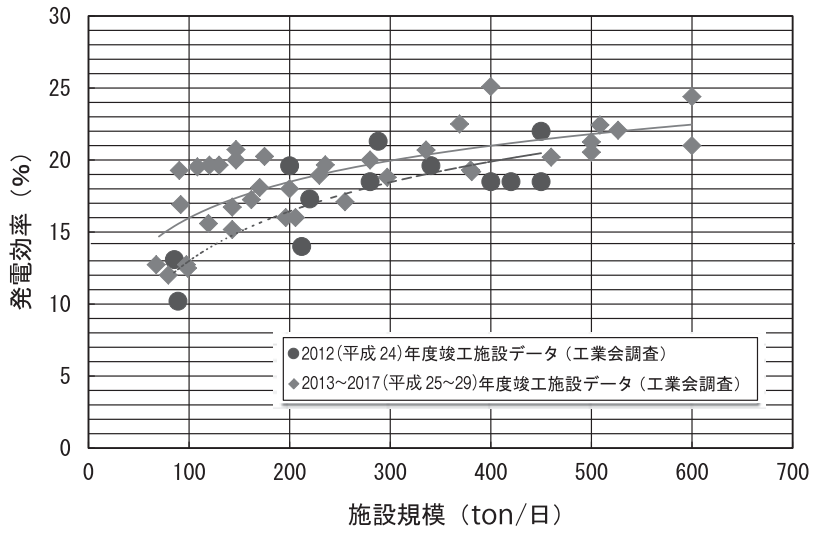

図 3 2013～2017 (平成 25～29) 年度竣工予定施設の発電効率 
だけでなく熱利用もカウントできる「エネルギー回収 率」の基準を設けた。

交付メニューの検討委員会では, 自治体の廃棄物処理 施設では大半が有効な熱利用先がない実情となっている との意見もあったが，将来的な熱利用の促進を図るため にも「発電十熱」で評価することとなった。

表 1 にエネルギー回収率の基準を示す。右闌に高効率 ごみ発電基準からの上乗せ割合を示しているが, 現時点 での技術レベルを鑑みてお抄むね 1.5～2.0\%程度となっ た。100 ton/日以下の施設の基準については, 規模が小 さいのに $4 \mathrm{MPa}, 400{ }^{\circ} \mathrm{C}$ のボイラを設備するのは費用対 効果としてどうなのかという議論の末 $15.5 \%$ となった。

\section{2 送電端効率の評価}

当初マニュアルの検討にあたり, 環境省より省エネも 推進したい旨を聞いており, 高効率なエネルギー回収と 省エネを同時に評価できる指標として送電端効率の基準 設定を検討した。結果, 灰を溶融する付加価值をもつシ ステム（ストーカ十灰溶融，ガス化溶融等）と単純焼却 するシステムとでは，たとえ同じ発電効率でも溶融する 負荷がないぶん単純焼却の方が送電端効率は高いことか ら，2〜3 システム別のグループに分けないと基準線を 設定できないことが判明した。基準を複数設けることは， それぞれの到達度合も同一にする必要があるが, 公平性 を担保した基準設定には至らなかった。

その代わり，温室効果ガス排出抑制等指針マニュア ル に)に記載されている施設の種類別の二酸化炭素排出量 の目安に適合するように努めることになった。

\section{$3.3 \times$ メンガス化施設}

マニュアルでは，おおむね 70 ton/日以下の小規模施 設では, 無理な発電施設計画とならないよう十分な検討 をするとともに，メタン発酵技術等を採用して高効率な

表 1 エネルギー回収率の基準

\begin{tabular}{c:c:cc}
\hline 施設規模（ton/日） & $\begin{array}{c}\text { エネルギー } \\
\text { 回収率 (\%) }\end{array}$ & $\begin{array}{c}\text { (前) } \\
\text { 発電効率 } \\
(\%)\end{array}$ & $\begin{array}{c}\text { 上乗せ } \\
(\%)\end{array}$ \\
\hline 100 以下 & 15.5 & 12.0 & 3.5 \\
100 超, 150 以下 & 16.5 & 14.0 & 2.5 \\
150 超, 200 以下 & 17.5 & 15.5 & 2.0 \\
200 超, 300 以下 & 19.0 & 17.0 & 2.0 \\
300 超, 450 以下 & 20.5 & 18.5 & 2.0 \\
450 超, 600 以下 & 21.5 & 20.0 & 1.5 \\
600 超, 800 以下 & 22.5 & 21.0 & 1.5 \\
800 超, 1,000 以下 & 23.5 & 22.0 & 1.5 \\
1,000 超, 1,400 以下 & 24.5 & 23.0 & 1.5 \\
1,400 超, 1,800 以下 & 25.5 & 24.0 & 1.5 \\
1,800 超 & 26.5 & 25.0 & 1.5 \\
\hline
\end{tabular}

表 2 メタンガス化施設の規模要件

\begin{tabular}{cc}
\hline 焼却施設規模 & メタンガス化施設規模 \\
\hline 200 ton/日未満 & 20 ton/日以上 \\
$200 \sim 500$ ton/日未満 & 焼却施設規模の $10 \%$ 以上 \\
500 ton/日以上 & 50 ton/日以上 \\
\hline
\end{tabular}

エネルギー回収に努めることとしている。さらに，焼却 施設にメタンガス化施設を併設するとすべての設備が交 付率 $1 / 2$ になるという政策的な誘導も考慮されている。

そこで, 表 2 に示すような焼却施設規模にリンクした メタンガス化施設の規模要件を設定し, 最低規模として 20 ton/日以上が交付要件とすることになった。

\section{4. 発電効率向上に係る技術的要素}

高効率ごみ発電施設整備マニュアル4゙ では, 以下の技 術の概要と施設計画にあたっての留意点を示している。

（1）より多くの熱を蒸気として回収するための技術（熱 回収能力の強化)

(1) 低温エコノマイザ

(2) 低空気比燃焼

（2）より蒸気タービンへ供給する蒸気を増やすための技 術・施策 (蒸気の効率的利用)

(1) 低温触媒脱硝

(2) 高効率乾式排ガス処理

(3) 白煙防止条件の設定なし, あるいは白煙防止装置 の運用停止

(4) 排水クローズドシステムの導入なし

（3）より効率良く電気に変換するための技術（蒸気ター ビンシステムの効率向上)

(1) 高温高圧ボイラ

(2) 抽気復水タービン

(3) 水冷式復水器

「(2) (3) 白煙防止条件の設定なし, あるいは, 白煙 防止装置の運用停止」,「(2) (4) 排水クローズドシステ ムの導入なし」は技術的要素というより, 自治体の政策 の一つであることから除外するとして, それ以外の項目 に関しては, 体感ではあるが,「(3) (3) 水冷式復水器」 以外は現状普通に導入されている技術となっている。

以下, 高効率ごみ発電施設整備マニュアルの施行以降 に報告，提案されている技術の一部を紹介する。

\section{1 EGR (排ガス再循環) + SNCR (無触媒脱硝) によ る NOx 低減技術}

昨年度あたりから各社による EGR（排ガス再循環） およびSNCR (無触媒脱硝) の組み合わせによる高効率 
な $\mathrm{NOx}$ 低減技術の報告がなされている。

各社の報告に共通していえるのは, EGR のみで NOx 濃度を 50〜 60 ppm に, SNCR を組み合わせて $30 \mathrm{ppm}$ 以下にすることが可能とあるが，施設の保証值となると 運転管理值やリークアンモニアとの関係もあり $40 \mathrm{ppm}$ あたりが触媒脱硝技術とのボーダーであろうか。

エネルギー回収型廃棄物処理施設整備マニュアルの中 にも発電効率向上技術として高効率無触媒脱硝技術を掲 載しており，図４に示すようにNOx 規制值によっては 排ガス再加熱器および触媒脱硝装置が不要となり, 発電 効率の 1〜 1.5\%の向上が期待できる。

なお，図 4 では尿素水を噴霧するフローであるが，ア ンモニアガスを吹込む提案が多い。また，安価な尿素を 購入しアンモニアに変換した上で炉内に供給するシステ ムを提案しているメーカもある。

\section{2 蒸気条件の高温高圧化}

ごみ焼却発電のように数千～数万 $\mathrm{kW}$ 程度の発電容 量であれば，現状の蒸気条件 $4 \mathrm{MPa}, 400{ }^{\circ} \mathrm{C} て ゙ 十$ 分であ り，ハイリスクな $500{ }^{\circ} \mathrm{C}$ 域にチャレンジする意味がない というのが業界の大数の意見であるが，一方で現状の過 熱器管材料で寿命を短くすることなくどこまで昇温可能 かの研究開発も盛んになってきた。恐らく 420〜 430 ${ }^{\circ} \mathrm{C}$, 高くても $450{ }^{\circ} \mathrm{C}$ がターゲットと思われるが, 比較的大規 模な施設であれば費用対効果の面で有効かもしれない。

また，流動床式焼却における炉内脱硫，脱塩効果によ り過熱器管の腐食環境がマイルドになり低合金鋼で対応
可能との報告もある。

\section{3 脱硝触媒の現地再生}

マニュアルに記載されている技術である。従来，脱硝 性能が低下した触媒は新品と交換するか, 触媒メーカ等 にて活性を回復させる触媒回復処理を行ったものを再利 用している。触媒メーカ等による再生の場合, 取り出し や輸送等で破損等のリスクがあるため, 通常 2 3 回程 度が再生の上限とされている。

図 5 に示すように脱硝触媒を設置した状態での触媒再 生が可能となれば, (1)触媒交換・再生に関わる維持管 理費の低減, (2)再生工期の短縮, (3) 発電量の増加（低 温触媒を採用することができる), (4)誘引ファン動力の 低減（触媒総量の削減につながり, 結果触媒反応塔での 圧力損失が低くなる）が可能となる。

\section{4 飛灰循環技術}

マニュアルに記載されている技術である。眓 6 に示す ように従来の乾式排ガス処理方法に加えて, バグフィル 夕で捕集された飛灰を再度バグフィルタ入口に投入する ことにより飛灰中に含まれる未反応消石灰を再利用する 方法であり, 薬剤量 (薬剤コスト) の低減および高効率 な除去が期待できる。

直接発電の高効率化に寄与する技術ではないが, 湿式 洗浄塔が不要になった場合は発電量の増加が見达める技 術である。

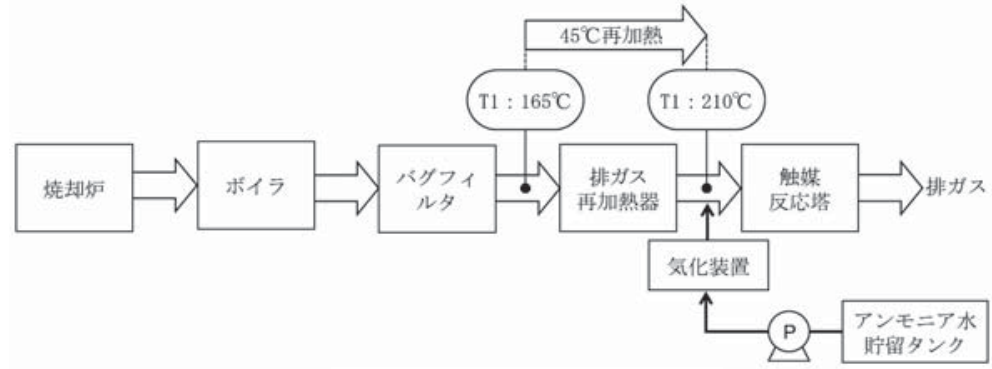

(a) 標準的な乾式排ガス処理フロー

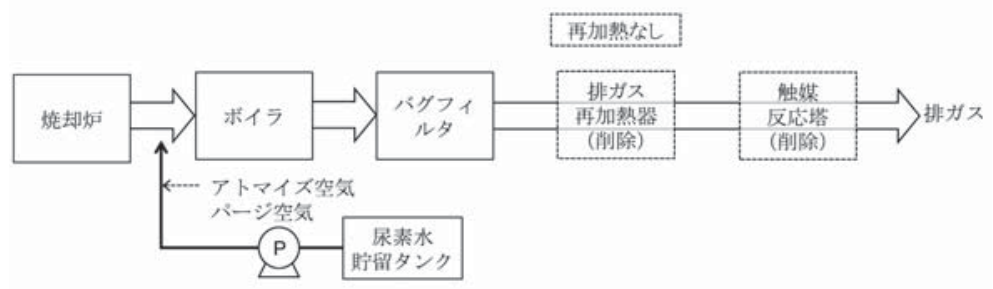

（b）無触媒脱硝を採用した場合

図 4 高効率無触媒脱硝技術 


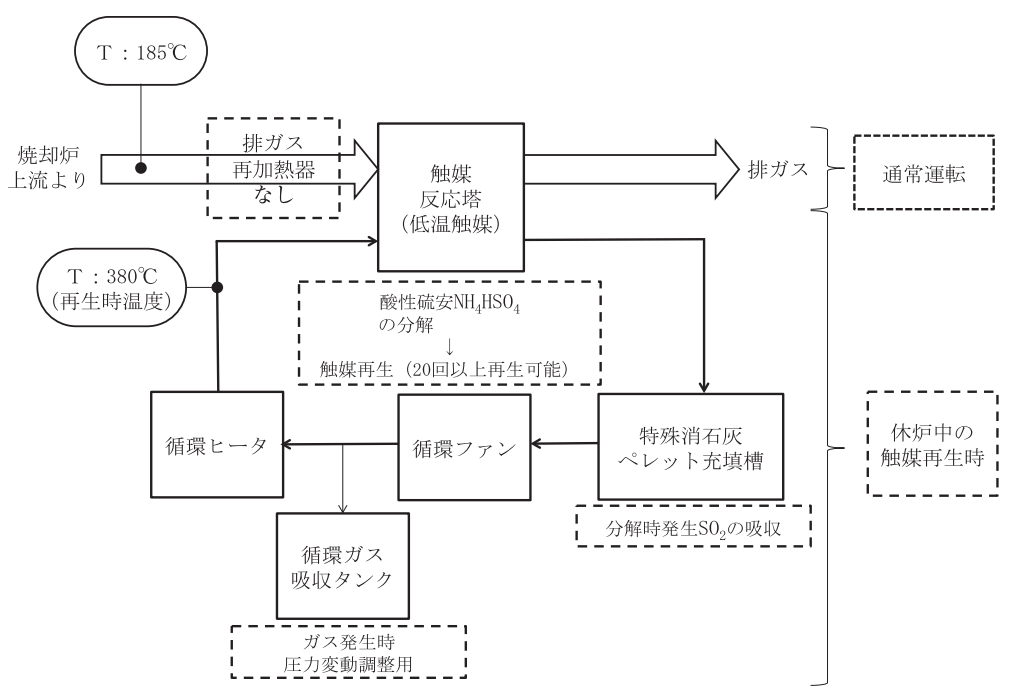

図 5 脱硝触媒の現地再生

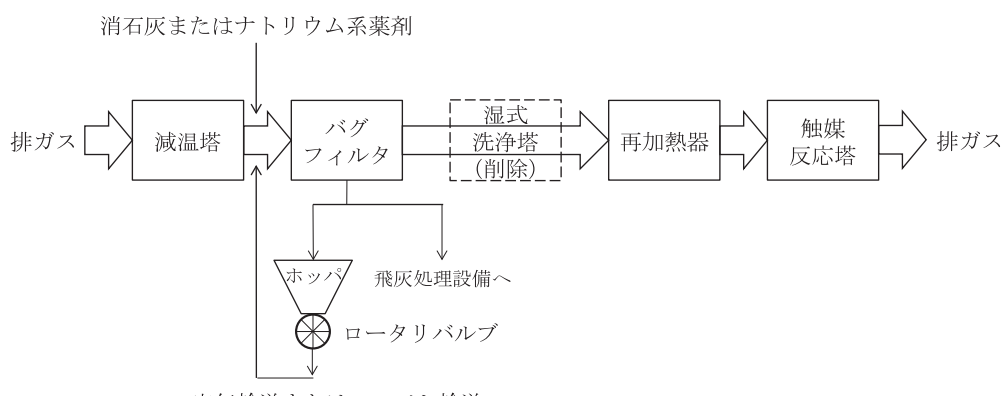

空気輸送またはコンベヤ輸送

図 6 飛灰循環システム

\section{5 膜処理による排水リサイクルシステム}

マニュアルに記載されている技術である。焼却処理施 設の排水は, クローズドシステムを採用している場合は 減温塔で噴霧蒸発処理される。このとき, 蒸発処理を行 うためにボイラ出口排ガス温度を高めに設定する必要が あり，その結果ボイラ効率が低下する。そこで, 場内排 水を膜により高度処理することで, 従来の再利用水では 使用できなかった機器冷却水等へ利用することにより, 噴霧蒸発処理する排水量を削減し, ボイラ出口排ガス温 度をより低温化することが可能となる。ボイラでの熱回 収量の増加, ひいては発電効率の向上が期待できる技術 である。

\section{6 その他}

発電の高効率化技術ではないが，昨今の国土強勒化へ 向けた取り組みの中で, 廃棄物処理施設の防災拠点化, エネルギー供給拠点化が推進されている。電力システム
改革の小売自由化への制度改革と併せて, 各社, 特定規 模電気事業者への登録, 外部電源が遮断した状態での市 役所等への電力供給, 送電電力のインバランス対策, 発 電施設のネットワーク化等ソフト面の検討が進められて いる。

その他, 変わり種としては, 筆者が第 36 回全国都市 清掃研究・事例発表会で座長を務めたセッションで, 腐 食抑制剂 (ゼオライト系) のボイラへの噴霧により過熱 器管の腐食界面での防食効果が期待できるという報告が あった。まだまだ詳細な調査が必要と思われるが, 高効 率発電へ向けた多方面からのアプローチがされているこ とを実感した。

\section{5. おわりに}

前述したように, 今後 5 年間の竣工予定施設の平均発 電効率が $20 \%$ を超える。廃棄物の性状および量の不安 
定さ，塩素や重金属類の含有による過酷な腐食環境，国 内の平均的な処理規模が 150 ton/日と小さいことなどを 考慮すると, あらためて日本の廃棄物処理技術の優秀さ を実感している。さらなる効率の向上には, 欧州のよう な施設規模の大型化が効果的であるが, 自区内処理の原 則等立ちはだかる壁は高い。

一方で, 昨今の防災拠点化, エネルギー供給拠点化等 スマートタウン的な構想も検討が進められており, 地域 に根ざした小規模ながら高効率な施設も求められている。 また, 火力発電所, バイオマス発電施設, 下水処理施設 等の施設とのコンバインドの検討も進められており, 都 市として最大限のメリットをみいだせるシステムの構築 が望まれている。

東日本大震災後の国土強勒化へ向けた検討や電力シス テム改革等, 社会インフラの変貌により, 廃棄物処理施 設のあり方も大きく変わろうとしている。工業会として 今後とも, 最新の情報の入手および最良の手法の提案を
していきたい。

\section{参 考文 献}

1) 環境省：エネルギー回収型廃棄物処理施設整備マニュ アル (2014)

http : //www.env.go.jp/recycle/misc/energy/index.html （閲覧日 2015 年 2 月 2 日）

2) 環境省 : 一般廃棄物処理事業実態調査の結果（平成 24 年度)について (2015)

http : //www.env.go.jp/recycle/waste_tech/ippan/h24/ index.html（閲覧日 2015 年 2 月 2 日）

3 ) 環境省: 温室効果ガス排出抑制等指針マニュアル (2012)

http : //www.env.go.jp/earth/ondanka/gel/ (閲覽日 2015 年 2 月 2 日)

4 ）環境省：高効率ごみ発電施設整備マニュアル (2009) http : //www.env.go.jp/recycle/misc/he-wge_facil/ （閲覧日 2015 年 2 月 2 日）

\title{
Trends in Waste-to-Energy Technologies for High Efficiency Power Generation
}

\author{
Susumu Uno \\ Japan Environmental Facilities Manufacturers Association (JEFMA) \\ (TAKUMA Co., Ltd.) \\ (Nihonbashi Cere Bldg., 2-8-4 Nihonbashihoridome-cho, Chuo-ku, Tokyo 103-0012 Japan)
}

\begin{abstract}
With regard to waste power generation in Japan, although average power generation efficiency for all existing facilities is currently only at approximately $11.9 \%$, the rate for facilities planned for completion in the next five years is at $20 \%$ or higher, and the improvement in efficiency is definitely progressing. Given the scheduled completion of these facilities, which will combine incineration facilities with methane fermentation facilities and aim to be small-scale, high-efficiency power generation facilities with capacities of 100 to 200 ton/day, circumstances surrounding waste treatment are steadily undergoing change. In this paper, some of the contents of a manual for the preparation of energy recovery type waste treatment facilities, which started in FY2014 with the involvement of JEFMA, are introduced. These include EGR+SNCR, high-temperature high-pressure waste heat boilers, on-site catalyst denitrification regeneration, fly ash circulation, waste water recycling systems using membranes, and other technologies for further improvement in efficiency.
\end{abstract}

Keywords : waste power generation, methane fermentation facility, energy recovery type, energy supply bases 